\title{
急性骨髄性白血病に続発した子宮頸部緑色腫の 1 症例
}

\author{
大阪警察病院研究検査科 \\ 黒川 和男 松木佐紀子 小塚 恒弘 \\ 大阪大学医学部第 2 病理 \\ 青笹 克之 山本茂生 \\ 阿部産婦人科 \\ 大内 和子 \\ 大阪府立成人病センター \\ 野田定
}

急性骨髄性白血病に緑色腫が発生することはよく知られているが，それが子宮に発生することは 極めてまれとされている．今回，著者らは 42 歳の婦人の子宮頸部に原発したと思われる緑色腫を 経験し，その子宮腟部擦過スメア中の細胞像を検討し得たのでここに報告する。な怙著者らの観察 した細胞所見は次のごとくである.

すなわち, 細胞形は円形〜類円形を示し, 細胞質はライトグリーン飞淡染し, 核形は円形〜不整 形で,なかには切れ込みを有するものも認めた。核縁は薄く, 核クロマチンは細網状〜細顆粒状で 微細なクロマチンが密に配列し，円形〜不整形で小型の核小体を1〜数個認めた。

Key words : Uterin cervix-Chloroma-AML-Cytology-Case-report

\section{1.はじめに}

急性骨骾性白血病 (以下, AML と略す) に緑色腫 (chloroma) が続発することはよく知られているが，そ

Cytologic Findings of the Chloroma in the Cervix Occurring in the Course of AML

Kazuo KUROKAWA, C.T., J.S.C., C.T., I.A.C., Sakiko MATSUKI, M.T. and Tsunehiro KOZUKA, M.T. Dept. of Clinical Laboratory, Osaka Police Hospital Katsuyuki AOZASA, M.D. and Shigeo YAMAMOTO Dept. of Pathology, Osaka University Kazuko OUCHI, M.D.

Abe Obstet. \& Gynec., Hospital

Sadamu NODA, M.D., Ph.D., F.I.A.C.

The Center for Adult Diseases, Osaka

Reprint request ⿶543 大阪市天王寺区小宮町 8 大阪警 察病院研究検査科

昭和 55 年 9 月 26 日受付
れが子宮に発生することはきわめてまれである2,4,5,8,9). 今回, われわれは子宮頸部に発生した緑色腫を経験 し, 子宮腟部擦過スメア中に腫瘍細胞を認めたのでその 細胞像を中心に組織像を加えて報告する.

\section{2. 症例}

患 者: S.T., 42 歳, 主婦.

主 訴: 不正性器出血.

既往歴：15 歳時虫垂切除術を受ける. 23 歳時交通事 故 (下腿外傷にて入院加療す).

家族歴：特記すべきことなし．

現病歴: 昭和 53 年 7 月初旬より不正性器出血を訴元 近くの婦人科医を受診し，子宮癌を疑われ，8月 14 日当 院産婦人科を受診. 8 月 14 日の子宮腟部擦過細胞診は, P.C. II, 内膜の組織診は脱落膜様変化の疑いであった. 
子宮筋腫の診断を受けたが， 8 月 28 日の血液検查にて 末梢血液中に $39 \%$ の芽球細胞を認めたため，9月 7 日 内科入院となる。

入院時現症 : 体格中等度, 栄養良, 身長 $153 \mathrm{~cm}$, 体重 $60 \mathrm{~kg}$, 意識明膫, 顔貌・皮膚・呼吸異常なし，脈 拍 76 ! $\mathrm{mm}$, 血圧 118/80 mmHg, 口腔・咽頭異常なし, 結膜貧血 および黄染なし, 心・肺異常なし, 肝・脾腫なし, 頸 部・腋窩・鼠径部にリンパ節を触知せず.

入院時検查所見 : 表 1 亿示すごとく未梢血 液中に 69 \%，また骨䯣穿刺により $76 \%$ の白血病細胞索認めた。 peroxidase 反応陽性で, Auer 小体も認められ AML の 所見であった。 その他の異常検査所見は便潜血の陽性所 見である(表 1 ).

入院後経過：9月 7 日 AML および子宮笳腫の診断の もとに入院し, DCMP 療法を開始した。9月 7 日よりダ ウノマイシン $(40 \mathrm{mg} /$ 日), キロサイド $(60 \mathrm{mg} / 5$ 日), $6 \mathrm{MP}(150 \mathrm{mg} / 4$ 日), プレドニン $(30 \mathrm{mg} / 4$ 日), 10 月 9 日よりダウノマイシン ( $40 \mathrm{mg} /$ 日)，キロサイド $(60 \mathrm{mg} /$ 4日), $6 \mathrm{MP}$ ( $150 \mathrm{mg} / 4$ 日), プレドニン ( $30 \mathrm{mg} / 4$ 日), 11 月 20 日よりダウノマイシン (40 mg/4 日)，キロサイド $(60 \mathrm{mg} / 2$ 日, $60 \mathrm{mg} \times 2 / 3$ 日), $6 \mathrm{MP}(100 \mathrm{mg} / 2$ 日), プレ ドニン (30 mg/4 日) の計 3 回実施した. 12 月 12 日より サイクロ C $(500 \mathrm{mg} / 4$ 日), プレドニン (30 mg/4 日) の $\mathrm{CCP}$ 療法を追加し, AML 軽減のため昭和 54 年 1 月 16 日単純子宮全摘術を施行した。 その摘出子宮の頸部にお ける病理組織診断は緑色腫で㔖った。

1 月 19 日より $38 \sim 39^{\circ} \mathrm{C}$ の発熱が続き, 1 月 23 日末梢 血の白血病細胞が $60 \%$ と再び上昇のため，1月 24 日よ りサイクロ C (500 mg/4 日), プレドニン (30 mg/4 日) の CCP 療法を実施したが, 1 月 27 日より肉眼的血尿が 出現し，3月 7 日呼吸不全にて死亡した。な扮剖検は行 われなかった。

表 1 Hematological findings

\begin{tabular}{lc|cr}
\hline \multicolumn{2}{c|}{ Peripheral blood $(9 / 7)$} & \multicolumn{2}{c}{ Bone marrow (9/6) } \\
\hline $\mathrm{RBC}$ & $330 \times 10^{4} / \mathrm{mm}^{3}$ & Nucleated cell count \\
$\mathrm{Hb}$ & $10.9 \mathrm{~g} / \mathrm{d} l$ & \multicolumn{2}{|c}{$3.8 \times 10^{4} / \mathrm{mm}^{3}$} \\
$\mathrm{Ht}$ & $31 \%$ & Leukemia cell & $76.5 \%$ \\
$\mathrm{Pl}$ & $11.6 \times 10^{4} / \mathrm{mm}^{3}$ & My & $2.0 \%$ \\
$\mathrm{WBC}$ & $15,700 / \mathrm{mm}^{3}$ & Meta & $1.0 \%$ \\
Leukemia cell & $69 \%$ & St & $0.5 \%$ \\
Seg & $1 \%$ & Eos & $2.5 \%$ \\
Eos & $3 \%$ & Ly & $3.5 \%$ \\
Ba & $1 \%$ & Plasma cell & $0.5 \%$ \\
Ly & $26 \%$ & W, Mit & $0.5 \%$ \\
ortho cromatic E. bl. & Megakaryocyte & $(+)$ \\
\multicolumn{2}{r}{} & Peroxidase R & Positive
\end{tabular}

手術所見：子宮は超鴊卵大で可動性悪々，両側基勒带 治固であり，右傍結合織は骨盤壁まで腫瘤を触れた。 卵巣，卵管には異常を認めなかった。腫瘍は頸部後唇よ り発生して打り，臸 $1 / 3$ 以下への浸潤が少られ，黄緑色 を呈した。よって単純子宮全摘抒よび両側付属器摘出を 行うも，胵断端の腫瘍は取り得ず，閉腹した。

\section{3. 細胞所見}

子宮腟部擦過スメアの Papanicolaou 染色での所見は, 多数の好中球および squamous metaplastic cell に混っ て N/C 比大なる小型の腫瘍細胞を散在性に認めた（図 1).

細胞形は円形〜類円形を示し，細胞質はライトグリー ンに淡染し，核形は円形〜不整形で，なかには切れ込み を有するものも認めた。核縁は薄く，楧クロマチンは細 網状〜細顆粒状で微細なクロマチンが密に配列し，円 形〜不整形で小型の核小体を 1 〜数個認めた（図 2 ).

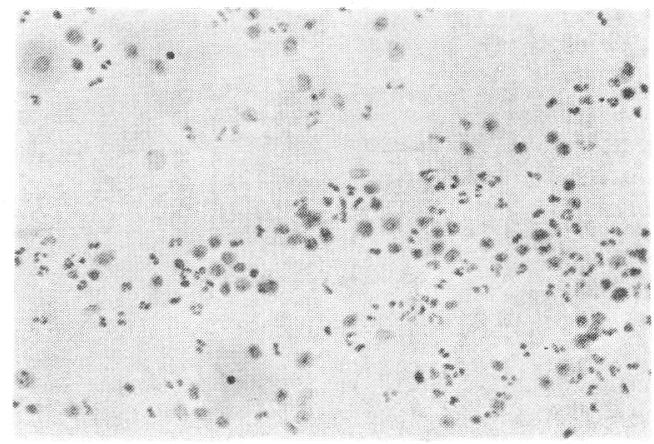

图 1 Pap. 染色 $\times 200$ (chloroma)：散在性に分布 寸る腫瘍細胞

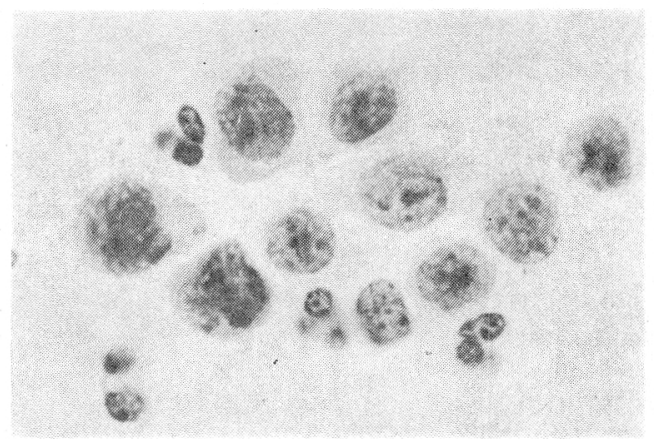

図 2 Pap. 染色 $\times 1,000$ (chloroma): 微細顆粒 状〜細網状の密なクロマチンを有する腫瘍細胞 


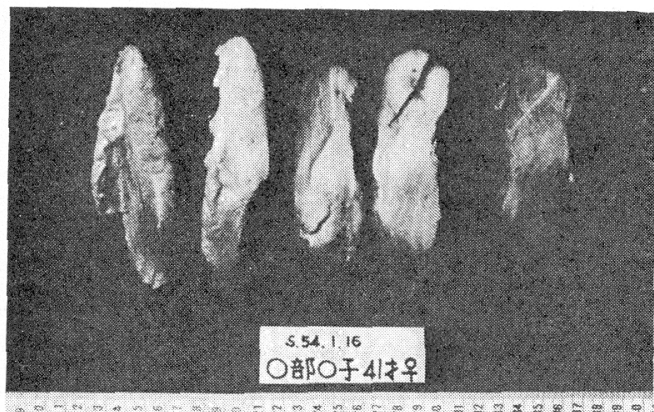

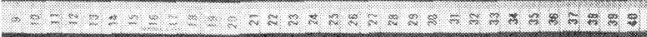

図 3 Macro：下部の濃い部分が緑色腫

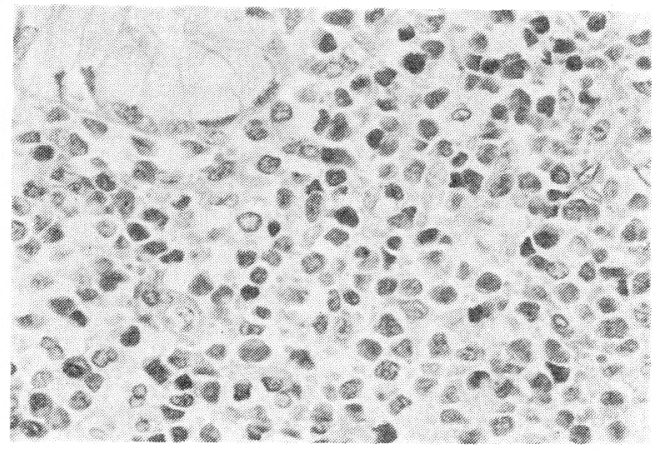

図 4 H.E. 染色 $\times 400$ (chloroma): 子宮胵部にみ られる腫瘍紏胞

\section{4. 病理組織所見}

macroscopic に注子宮胵部に main tumor 老認め, 緑 色䒚呈していた（図３）. micro 的には腫瘍細胞は子宮腟 部任集塊となって存在したが，体部へびまん性に浸潤が みられた。内膜拉よび左右卵巣にも浸潤がタられたが， 腫瘤形成はなかった (図 4 )。この腫瘍細胞は naphthol一 ASD-chloroacetate 染色で陽性を示した。

\section{5. 考察}

緑色腫快，chloromyeloma， chloromyelosarcoma， granulocytic leukosarcoma, granulocytic sarcoma, myeloblastoma, myelocytoma, myelosarcoma などとも 呼ばれ ${ }^{5}$, Wintrobe ら ${ }^{9\rangle}$ は, 緑色腫とは granulocytic neoplasia の限局性の腫瘤に適用された術語であって, 高頻度に眼窝部を侵すむのとし, その名前の由来は細胞 内の lysosome 内にある myeloperoxidase が光に当たる と変化し, 腫瘤の割面が緑色に変わることによるとされ ている。 また同し緑色腫瘤においても，その腫瘤境界が 明瞭でないものは chloroleukemia として区別されてい る5).
表 2 Cytological differences between chloroma and RS

\begin{tabular}{|c|c|c|c|}
\hline & & Chloroma & RS \\
\hline & 細胞閒結合 & 疎 & 柾 \\
\hline 細 & 性 状 & $\begin{array}{l}\text { 微 細 顆粒状 } \\
\text { 円形 類円形 }\end{array}$ & $\begin{array}{c}\text { 小空胞状 } \\
\text { 類 以形 不整 形 }\end{array}$ \\
\hline & 突 起 & な し & あ \\
\hline 胞 & 染色性 & 淡緑色 & 淡 緑 色 \\
\hline & 辺縁 & 明 瞭 & “明瞭〜やや不明瞭 \\
\hline 質 & 平均長径 $(\mu)$ & $11.6( \pm 1.9)$ & $11.0( \pm 2.4)$ \\
\hline & 平均短径 $(\mu)$ & $9.4( \pm 1.3)$ & $9.3( \pm 2.1)$ \\
\hline & 形 & $\begin{array}{l}\text { 円形〜類円形 } \\
\text { 切れ込み，へこ } \\
\text { み }\end{array}$ & $\begin{array}{l}\text { 円形〜類円形 } \\
\text { くびれてへこみ, } \\
\text { 切れ込み }\end{array}$ \\
\hline & 核 緑 & 肥厚なし & やや肥厚あり \\
\hline 核 & & 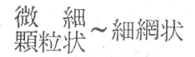 & 細網状～粗網状 \\
\hline & クロマチン分布 & 均等 (密) & 均 等 \\
\hline & 平均長径 $(\mu)$ & $9.4( \pm 1.3)$ & $8.4( \pm 1.4)$ \\
\hline & 平均短径 $(\mu)$ & $7.8( \pm 1.0)$ & $7.4( \pm 1.0)$ \\
\hline 核 & 形 & 類円形～不整形 & $\begin{array}{l}\text { 円形 不整形, } \\
\text { 棒状 }\end{array}$ \\
\hline 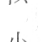 & & 明瞭～不明瞭 & 明 瞭 \\
\hline 小 & 数 & 小型で数佔 & 大型で 1 数 個 \\
\hline 体 & 平均長径 $(\boldsymbol{\mu})$ & $1.3( \pm 0.6)$ & $2.1( \pm 0.7)$ \\
\hline & 平均短径 $(\mu)$ & $1.0( \pm 0.4)$ & $1.7( \pm 0.5)$ \\
\hline
\end{tabular}

発生年齢は成人に比べ若年者に多く, 1937 年までの報 告例では $75 \%$ が 18 歳以下である5)。またその発生部位 は眼窩に最も好発し，そのほかでは卵巣が多く，ついで 甲状腺, 胸腺, 肺, 胃, 膵, 腸, 膀胱とつづき, 頻度は 少ないが，肝，脾にも発生する2,4,5,8,9)。Liu らら2) は， 1948 年から 1969 年の間に広島扔よび長崎において剖検 を行った骨髄性白血病患者 338 名のうち 23 名に緑色腫 を認めた。穴の好発部位は骨 (91\%), 卵巣 $(75 \%)$, リン 八節 (57\%), 腎藏 (48\%), 硬膜 $(39 \%)$, 肺 $(26 \%)$, 腕 $(26 \%)$, 乳房 $(25 \%)$, 脳 ( $22 \%)$, 腸 $(17 \%)$, 胸 $(17 \%)$, 腿 $(17 \%)$ であり，子宮への発生は1例のみであり，今 回われわれの経験した子宮緑色腫は非常にまれである。

また Wiermik らつは reticulum cell sarcoma (RS) と の鑑別診断を強調している。よって, Papanicolaou 染色 での chloroma とRS の㧍のおのの細胞所見を表 2 に対 比し示した.

そのおもな点は, 細胞質に抒いては chloroma ではラ イトグリーンに淡染し, 微細な顆粒状を呈し, 円形〜類 円形で辺縁は明膫であり, RS では小空胞状を呈し，類円 形〜不整形で細胞辺縁は明膫〜やや不明膫で，なかには 突起を有するものもあり, chloroma よりやや大小不同 が目立った。核形においてはどちらも円形〜類円形で, 


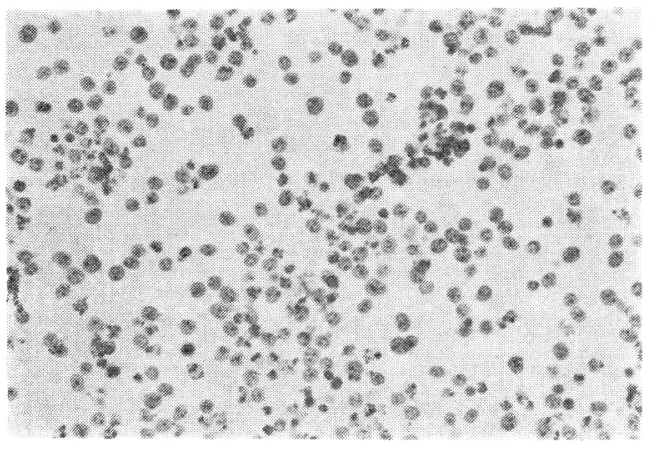

図 5 Pap. 染色 $\times 200(\mathrm{RS})$ : 散在性に分布与る腫 瘍細胞

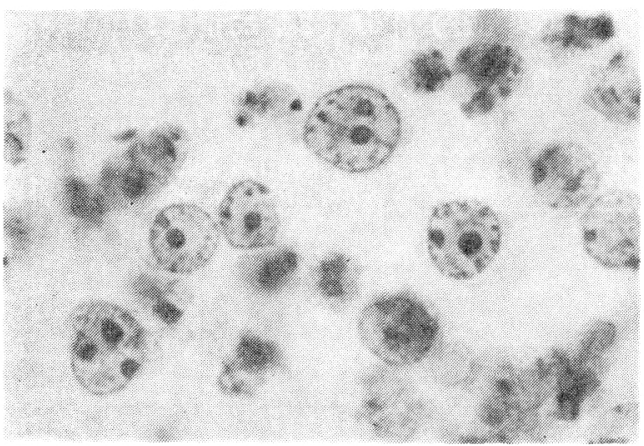

図 6 Pap. 染色 $\times 1,000(\mathrm{RS})$ : 粗網状のクロマチ ンで大型の明瞭な核小体在有寸る腫穆細胞

くびれや切れ达みを有するが，RS ではより多形性の傾 向をみた。核縁は chloroma に比較し, RS にやや肥厚を 認めた。核クロマチンはRS の細網状〜粗網状に対し, chloroma は細顆粒状〜細網状の微細なクロマチンが密 な分布を示した。核小体に掠いては chloroma は類円形 〜不整形で明瞭なものを単個で垫めるが，大部分のもの には小型で不明膫なものを数個認め, RS では円形〜不 整形の大型で明瞭なものが 1 数個みられた。 また平均 核小体径では RS の大型化が優位であった（図 5,6)。

以上のように核小体, 核ク口マチン，执よび細胞質に 差異索認めた。これらの細胞所見により, Papanicolaou 染色においての chloroma と RS との鑑別が可能である と考える.

\section{6.むすび}

以上，子宫頸部に発生した緑色腫について文献的考察 を加え, その細胞像, 組織像および reticulum cell sarcomaとの鑑別について報告した。

稿を終えるにあたり，資料を提供いただいた当院婦人科高山

\author{
克己部長および田坂慶一先生に感謝致します。 \\ 本論文の要旨は第 18 回日本臨床細胞学会秋期大会（大阪）に \\ おいて発表した。
}

\section{Summary}

In a 42-year-old woman with genital bleeding, "Leiomyoma" was diagnosed in the uterus, but preoperative examination revealed that she was affected by AML. The uterus operatively resected was larger than henegg in size, and the tumor mainly situated in the cervix. Cut surface of the tumor colored yellowish-green. Microscopically, infiltrations of the tumor cells were seen in the corpus uteri and ovaries.

The disease was diagnosed as chloroma of the uterus. Retrospective observation of the smears from the cervix revealed relatively small-sized tumor cells. Difficulty in differential diagnosis between chloroma and RS has been commented in the literatures, but differences from the latter were observed in the nucleoli, chromatin pattern and the nature of the cytoplasms in this patient. The chloroma in the uterus as reported here is a very rare condition.

\section{文献}

1) Custer, R.P. : An Atlas of the Blood and Bone Marrow, 313 322, W.B. Saunders Co., Philadelphia, 1974.

2) Liu, P.I., et al. : Autopsy study of granulocytic sarcoma (chloroma) in patients with myelogenous leukemia, Hiroshima-Nagasaki 1949 1969, Cancer, $31: 948 \sim 955,1978$.

3) Luksch, Fr.: Leukemic cells in vaginal smears, Acta cytol., 8: 95, 1964.

4) Muss, H.B., et al. : Chloroma and other myeloblastic tumors, Blood, 42:721 728, 1973.

5) Rappaport, H. : Atlas of Tumor Pathology ; Tumors of the hematopoietic system, 241 243, Washington, D.C., Armed Forces Institute of Pathology, 1963.

6) 上井良夫・他：白血化以前の臸スミア細胞診で白血病細胞 孝認めた急性骨髄性白血病の1例，癌の䧗床，18：927〜 931, 1972.

7) Wiermik, P.H., et al. : Granulocytic sarcoma (chloroma), Blood, 35:361 369, 1970.

8) Williams, W.J., et al. : Hematology, Ist ed., 717, McGraw-Hill Book Co., 1972.

9) Wintrobe, M.M., et a1. : Clinical Hematology, 7th ed., 1477 1478, Lea \& Febiger, Philadelphia, 1974. 